\title{
Socio-economic factors threatening the survival of Ganges River Dolphin Platanista gangetica gangetica in the upper Ganges River, India
}

\author{
Tawqir Bashir ${ }^{1}$, Afifullah Khan ${ }^{2}$, Sandeep Kumar Behera ${ }^{3}$ \& Parikshit Gautam ${ }^{4}$ \\ Present Address: ${ }^{1}$ Wildlife Institute of India, Post Box. \# 18, Chandrabani, Dehradun, Uttarakhand 248001, India \\ 1,2 Department of Wildlife Sciences, Aligarh Muslim University, Aligarh, Uttar Pradesh 202002, India \\ 3,4 Freshwater and Wetland Division, WWF-India, 172 Lodhi Estate, New Delhi 110003, India \\ Email: ${ }^{1}$ tbashir@wii.gov.in; ${ }^{2}$ afifkhan@ rediffmail.com; ${ }^{3}$ sbehera@wwfindia.net; ${ }^{4}$ pgautam@wwfindia.net
}

Date of publication (online): 26 July 2010 Date of publication (print): 26 July 2010 ISSN $0974-7907$ (online) | 0974-7893 (print)

Editor: Gill Braulik

\section{Manuscript details:}

Ms \# 02333

Received 19 October 2009

Final revised received 16 July 2010

Finally accepted 17 July 2010

Citation: Bashir, T., A. Khan, S.K Behera \& P. Gautam (2010). Socio-economic factors threatening the survival of Ganges River Dolphin Platanista gangetica gangetica in the uppe Ganges River, India. Journal of Threatened Taxa 2(8): 1087-1091.

Copyright: (c) Tawqir Bashir, Afifullah Khan, Sandeep Kumar Behera \& Parikshit Gautam 2010. Creative Commons Attribution 3.0 Unported License. JoTT allows unrestricted use of this article in any medium for non-profit purposes, reproduction and distribution by providing adequate credit to the authors and the source of publication.

For Author Details \& Author Contribution see end of this article.

Acknowledgment: We are grateful to Aligarh Muslim University for providing us the facilities required for conducting this research. We also express our thanks to WWF-India for providing financial support. Mr. Satish Sharma, Range Officer, Narora Division was very helpful and cooperative in terms of official permissions regarding our surveys. Last but not the least we thank our field assistants, Parmanand, Radhey Shyam, Kale and Rajkumar for their rigorous efforts during the surveys.
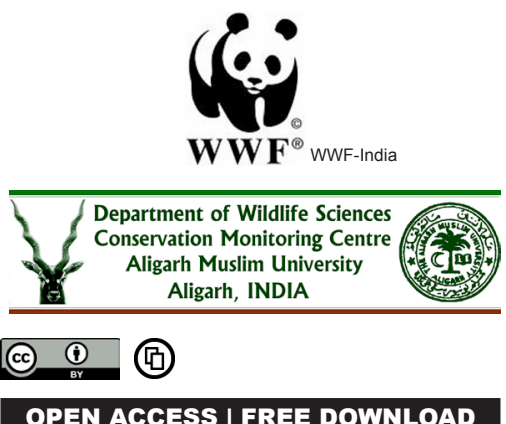

OPEN ACCESS I FREE DOWNLOAD

\begin{abstract}
The present study was conducted along the upper Ganges River between Narora barrages and Anupshahar from January to June 2007. Community interviews were conducted in order to assess the socio-economic profile of the fishermen community, their level of dependence on the river and their attitude towards the conservation of Ganges River Dolphin Platanista gangetica gangetica. The estimated literacy rate from interviews was $45 \%$, and average annual income per household was 27,000 INR (Indian National Rupee). The respondents were found to be well aware of the river biodiversity and believed excessive water extraction and pollution to be the responsible for any perceived decline in the dolphin population. About $55 \%$ of the fishermen were found to fish for commercial purposes, and a majority of them (71\%) used nylon gill-nets. A majority $(94 \%)$ of respondents that had boats of their own fished in the middle of the river, an activity often conducted in groups. $12 \%$ of respondents reported to have encountered dolphin carcasses. Excessive fishing and dolphin poaching were found to be interrelated; if fishing can be more effectively managed poaching may automatically decline. $41 \%$ of the fishermen interviewed were found to be willing to stop fishing providing adequate alternative livelihoods are provided by the government.
\end{abstract}

Keywords: Carcasses, fishermen community, Ganges River Dolphin, gill-nets, livelihood, Platanista gangetica gangetica, socio-economics.

\section{INTRODUCTION}

The Ganges River passes through northern India and has enormous cultural and economic significance. It is worshipped as a goddess by Hindus and is a centre of social and religious tradition (Adel 2001); however, it is one of the most polluted and highly exploited rivers in the world. It supports about $8 \%$ of the world's population living in its catchments (Newby 1998), directly or indirectly depending on it for their livelihood. As a result, the Ganges River Dolphin Platanista gangetica gangetica - one among the two subspecies of Platanista gangetica (the other being the Indus River Dolphin P. gangetica minor inhabiting Indus River), comes into direct competition with people either for food (fish) or space or indirectly faces threats due to pollution. The Ganges River Dolphin, locally known as 'Susu' is distributed along the Ganges, Brahamputra, Karnaphuli-Sangu and Meghna River systems and their tributaries, from the foot hills of the Himalaya to the limits of the tidal zone in India, Bangladesh, Nepal, and Bhutan (Anderson 1879; Jones 1982; Reeves \& Brownell 1989; Sinha 2000). The subspecies is positioned at the apex of food chain in the freshwater ecosystem and plays a vital role in maintaining its ecological balance (Behera 1995). In spite of being a "Flagship" species, representing an ecosystem in need of conservation (Behera 1995; Choudhary et al. 2006; Behera et al. 2008; Bashir 2010) its status has become a matter of grave concern over the past few decades. Its population has declined in range, and frequent incidental killings in gill-nets and threats to its habitat have compelled conservationists to list it as a Schedule I species in the Indian Wildlife (Protection) Act, 1972 and also classify it as Endangered (Smith \& Braulik 


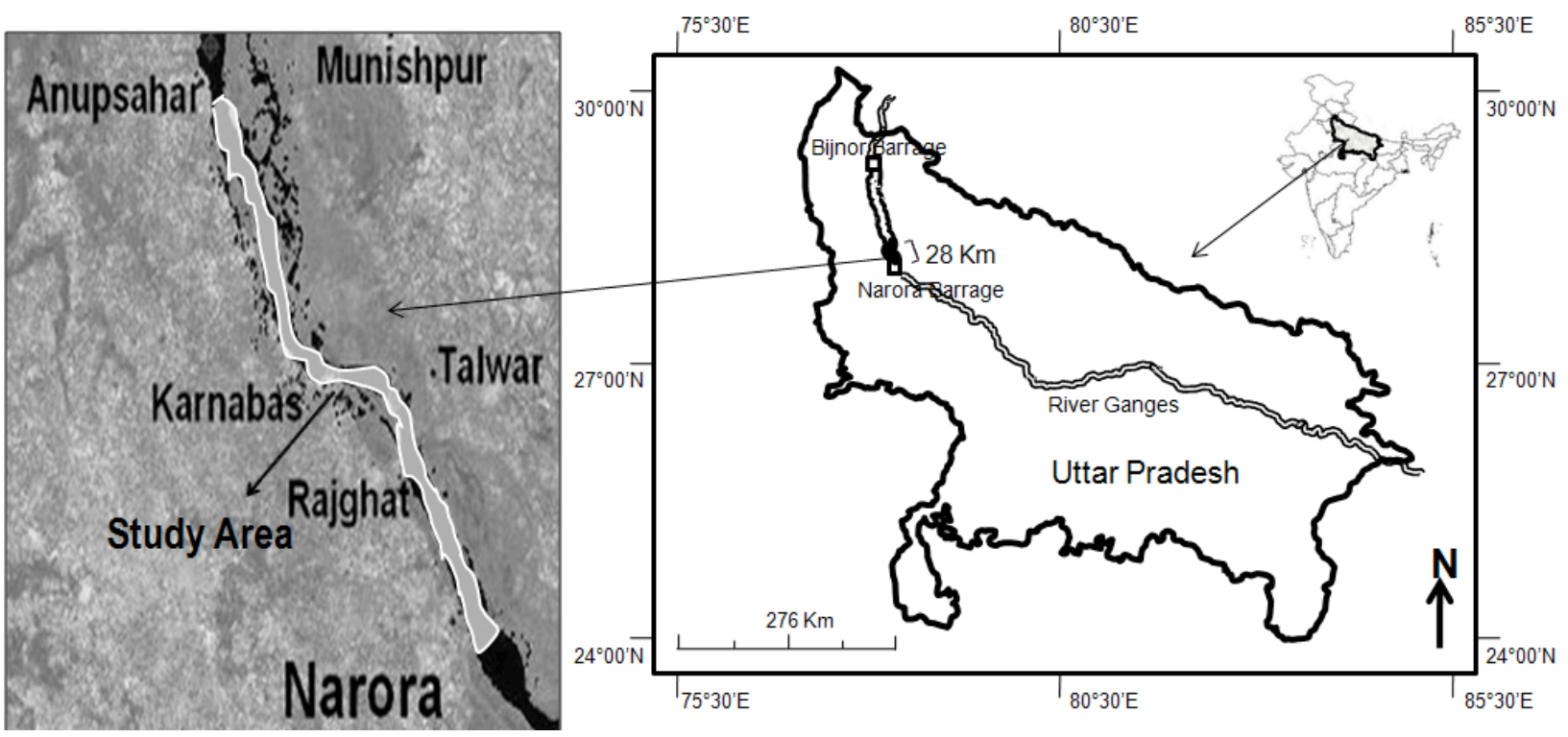

Figure 1. The location of the study area in Uttar Pradesh, India. Source: WWF-India

2008). The subspecies is also facing the consequences of habitat fragmentation through the construction of dams and barrages which has partitioned the meta-population into isolated sub-populations (Choudhary et al. 2006; Bashir et al. 2007). Its distribution range is continuing to shrink and it has been eliminated from many of the smaller tributaries and upper reaches of the Ganges system (Sinha \& Sharma 2003).

The main threats to dolphins survival are construction of barrages, heavy siltation, use of chemical fertilizers and organochlorines pesticides for farming in the river corridor, bycatch in gill-nets, prey depletion and intentional killings for oil and meat (Nair 2009; Sinha \& Sharma 2003). In order to achieve the goal of sustainable conservation of the subspecies the present study was conducted to quantify the socio-economic condition of the fishermen communities, their dependence on river resources, and their attitude towards the dolphin in its only viable habitat within the upper Ganges River (Behera 1995).

\section{MATERIAL AND METHODS}

In order to achieve the objectives of the study, a stretch of $28 \mathrm{~km}$ from Narora Barrage (28011'28.4"N \& 78023'48.1" $\mathrm{E})$ to Anupshahar $\left(28^{\circ} 21^{\prime} 52.0^{\prime \prime} \mathrm{N}\right.$ \& $78^{\circ} 16^{\prime} 24.8^{\prime \prime E}$ ) was specified for socio-economic interview surveys in the villages located along the banks of the river (Fig. 1). The interviews were conducted with individuals of a household mainly family heads (male or female) generally in the presence of rest of the family members using a semi-structured questionnaire (Choudhary et al. 2006). Eleven villages where nearly $60 \%$ of the residents were fishermen were targeted, out of which $35-40 \%$ of households were randomly selected for interviews, representing a total of 217 households. These villages were selected based on their direct dependence on the river. The households were interviewed about their socioeconomic status, dependence and perception towards the Ganges River and its fauna, and their attitude towards conservation of the Ganges River Dolphin.

\section{RESULTS}

\section{Socio-economic profile and awareness}

The estimated literacy rate among the sampled households was $45 \%, 21 \%$ of which were educated to secondary level and the rest to primary level. Although, the literacy rate among the children was $63 \%$ only a small proportion (17\%) were receiving education to secondary level. The overall sex ratio of the sampled households was $0.87: 1.00$ (female/male) with $27 \%$ females literate to primary level and $51 \%$ males literate $(68 \%$ to primary level). The average annual household income was about ₹ 27,000 (Indian National Rupee), with each household having an average of five family members. The communities also rear livestock with an average of 2-3 animals/family.

Of the total inhabitants interviewed $98 \%$ confirmed the presence of different species of fishes, turtles, and dolphins, whereas $32 \%, 15 \%$ and $3 \%$ reported the presence of crocodiles, snakes and otters respectively, in this stretch of the Ganges. 25\% of respondents reported less than 25, 60\% (25-50), 10\% (50-75) and $5 \%$ (> 75) fish species present in this stretch. 34\% of the respondents reported the dolphins to be distributed up to Brijgath (82km upstream of Narora) while the rest 


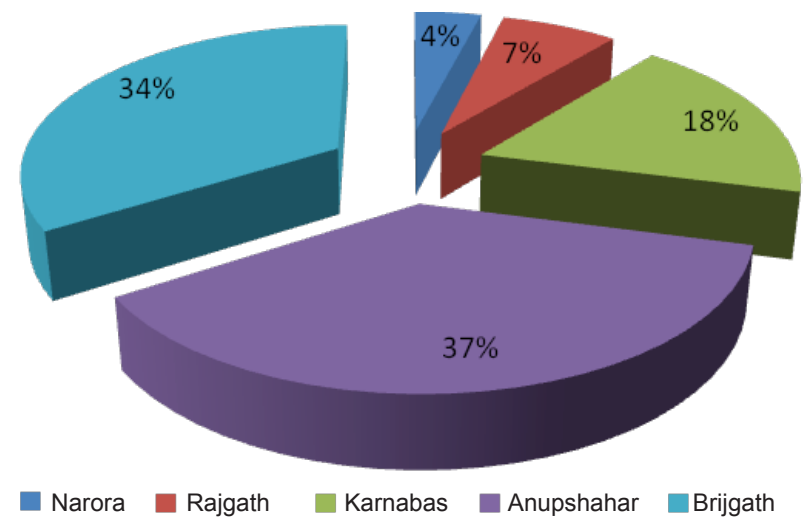

Figure 2. Perception of fishermen about dolphin distribution in the Upper Ganges River.

believed the same to be restricted only up to Anupshahar (Fig. 2). 19\% of the respondents reported an estimate of more than 75 dolphins surviving between Narora and Anupshahar, while 32\% (50-75), 30\% (25-50) and 19\% believed the number to be less than 25 individuals. The respondents had mixed views regarding the dolphin population trend with $53 \%$ believing an increase and rest $(47 \%)$ decrease in population over the years. When asked about the reasons for decreasing population trend of the dolphin, $59 \%$ of respondents held decreasing water level (over extraction) responsible while 30\% believed it was due to increasing water pollution (both being interrelated), only $3 \%$ believed increasing bank cultivation to be the culprit, while the remainder had no idea about the causes. However, no poaching and decrease in poaching were given as reasons for a perceived increase in the dolphin population by $72 \%$ and $10 \%$ of the respondents respectively, while the rest believed the fast propagation (breeding success) of the subspecies to be the reason for the increase. Almost all the respondents believed the Ganges River to be sacred, considering the dolphin as its guards and watchdogs, and all of them anticipated the continued survival of both. Most believed that fishing is detrimental to the dolphin, but all of them argued that they do not have any alternative. When asked about any help from the government they were found to have a negative perception towards it, but a good proportion (41\%) of the inhabitants were found willing to leave their fishing practices if provided with alternatives by the government, sufficient to fulfill their livelihood requirements.

\section{Dependence and threats}

Although, $75 \%$ of the fishermen households primarily conducted fishing they also practiced agriculture on their own land or land taken on lease along the river banks. They used chemical fertilizers at an average of 20-25 g/ plant. Also, profits from fishing were very small as they were bound to share a huge portion $(60 \%)$ of their catch with the fish contractors. $12 \%$ of the total respondents

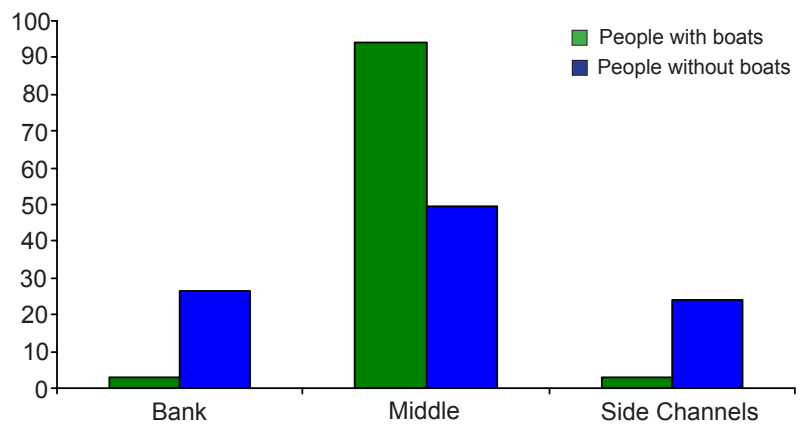

Figure 3. Modes and areas of fishing between Narora and Anupshahar.

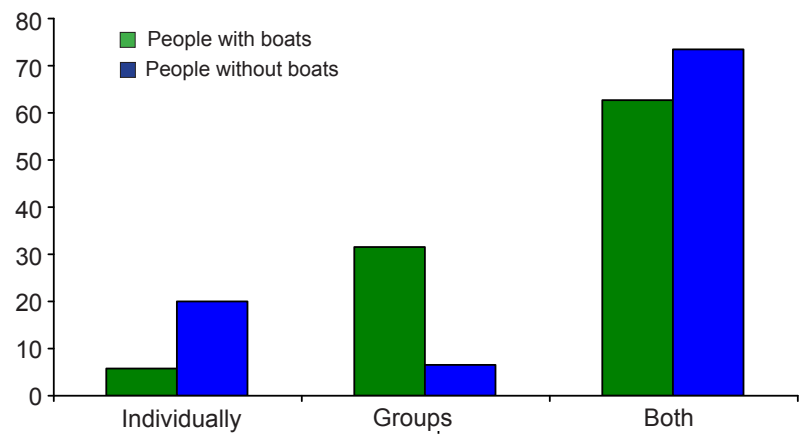

Figure 4. Modes and strategies of fishing between Narora and Anupshahar.

fish for commercial (exclusively for selling) purpose, $45 \%$ for subsistence (for own use) while $43 \%$ for both the purposes; however they added that the sale of fishes depends upon the size of the catch, which if small was kept for their own use and when large the remaining was sold in the market. It was reported that $44 \%$ of the respondents used gill-nets of size ranging from $2-15 \mathrm{~cm}$ (mesh size), 29\% used hook- thread while the remaining $27 \%$ were found to use both types of gears for fishing, depending on their intention. Only $32 \%$ of respondents had their own boats of which $94 \%$ fished in the middle of the river, and $31 \%$ did the same activity in groups. Even among people having no boats of their own, $49 \%$ used to fish in the middle of river by borrowing boats from their fellow fishermen, but only $7 \%$ of these fished in groups (Figs. 3 \& 4). Frequent visits to the local fish market by the interview survey team indicated consistent availability of fish below the permissible fish weight $(250 \mathrm{~g})$ for sale.

Although the fishermen generally hesitated when asked about any incidents of dolphins being caught in their nets, $4 \%$ agreed to the fact and reported that they released the animal even if they had to cut or spoil their nets to do so. Yet $23 \%$ of the respondents were well aware of dolphin oil price (₹ 4000-5000/litre) in the black market and also a small proportion of the respondents $(8 \%)$ hesitantly reported the use of dolphin oil to improve their fishing. $12 \%$ reported sighting of dolphin carcasses 
at different banks over different years.

\section{DISCUSSION}

The socio-economic profile of the fishermen community clearly states their level of poverty which necessitates the importance of earning a living above obtaining education even in early childhood. Rearing livestock does not provide substantial improvements to their socio-economic status. The result is that fishermen have few economic opportunities other than continuing to fish for subsistence or commercial purposes.

The study indicates that the fishermen community had a fairly good knowledge of the river biodiversity. Being more focused towards the fishes, their perception about the fish species in the stretch is in accordance with the documented estimates (Jayaram 1999; Behera 2002). The fluctuations in their perceptions regarding dolphin distribution may be influenced by their past knowledge, amount of time spent fishing in different seasons, and migration patterns of dolphins in different seasons. However, reports regarding dolphin numbers can be considered as over estimates when compared with the more quantitative scientific abundance estimate of 28 individuals in the study stretch (Bashir et al. 2010), influenced by their inadequacy in interpreting repeated dolphin surfacing to different individuals. Their mixed views concerning the dolphin population trends indicates that according to their memory and perception there have not been any major changes in the Ganges Dolphin abundance, although dedicated field surveys indicate that the dolphin population has increased in the study stretch but not at a rapid rate (Behera \& Rao 1999; Bashir et al. 2010). The entire Ganges basin is polluted by an annual usage of 2573 tones of pesticides and 1.15 million metric tones of chemical fertilizers in its catchment area (Gupta 1984). The use of the same in agriculture along the river banks may directly affect the water quality of the river and make it undesirable for the dolphin. High levels of pollution may lead to lowered immune ability of dolphins to respond to naturally occurring diseases (Lahvis et al. 1995) or impair their reproductive system, as observed in common seals (Reijinders 1986).

The study inferred that poverty compels the fishermen to fish but the harassment by fish contractors encourages them towards excessive fishing. Since most of the fishermen use large meshed gill-nets they are focused on catching large sized individuals and therefore assumed to be conducting commercial fishing (55\%). Use of boats for fishing in groups in the middle of the river may result in an increase in the frequency of incidental killing of dolphins in the nylon gill-nets of large mesh sizes (Behera 1995; Hassan et al. 1998). Substantial catches of small fish, below the permissible weight may result in dolphin prey depletion (Mohan et al. 1997) and potentially affect the sustainability of Ganges River fisheries. Poaching and intensive fishing are interrelated as the later requires dolphin oil as fish bait. The reports of dolphins entangled in gill-nets, the sighting of carcasses, and awareness about dolphin oil prices, suggests that some dolphin poaching may be occurring in the area.

Overall, it was observed that the Ganges River is respected by all the people irrespective of their castes and religion, but none of them would miss a chance to exploit its resources for their subsistence or commercial benefits. Yet their attitude towards dolphin conservation suggests a safe future for the species, provided the government plays an active role.

\section{CONCLUSION}

The Ganges River Dolphin is an indicator of riverine health, and like the river it is in a bad way. Besides being helpless towards its unhealthful home, many dolphins die getting entangled in gill-nets. Time is fast running out to save the dolphin but the concerns of the fishermen can also not be neglected, as the Ganges has been serving as a source of subsistence for them since time immemorial. There is a need to make efforts through a number of routes to prevent the extinction of this charismatic freshwater dolphin and enable the fishermen to achieve better living standards and understand the conservation importance of the species in a way that both ecology and economy are sustainably strengthened.

\section{RECOMMENDATIONS}

There is a need for awareness of fishermen regarding the importance of aquatic ecosystems so that they realize its significance for both the conservation of wildlife and also their own sustenance. Fishermen communities should be helped to obtain better educational opportunities. Alternatives to fishing as a livelihood, such as eco-tourism which would surely result in the reduction of pressure on the fish population and hence to the dolphin should be explored. Periodic monitoring of the dolphin population needs to be carried out, possibly by launching a 'Project Dolphin' at the national level similar to that of Project Tiger. The level of pollution needs to be frequently monitored and the effluents need to be treated to less hazardous products before discharge. Infrastructure should be developed to generalize the use of manure and natural fertilizers instead of chemical fertilizers and organochlorine products. Round-the-clock fishing and fishing during dolphin birthing season (Oct-Mar) especially at the time of peak birthing (Dec-Jan) months (Nowak 2003) should be prohibited by the law. A team of local conservation oriented volunteers should be designed to report any concerned illegal activity in the river stretch 
so that immediate actions could be taken. Since illegal fishing is encouraged by the fish market, adequate actions should be taken by the government against the fish contractors by stringently implementing the law and imposing fines against them.

\section{REFERENCES}

Adel, M.M. (2001). Effect on water resources from Upstream Water Diversion in the Ganges Basin. Journal of Environmental Quality 30: 356-368.

Anderson, J. (1879). Pisces, pp.863-869. In: Anderson, J. (ed.). Anatomical and Zoological Researches; Comprising an Account of the Zoological Results of the Two Expeditions to Western Yamuna in 1868 and 1875, and a Monograph of the Two Cetacean Genera, Platanista and Orcella. Bernard Quaritch, London.

Bashir, T. (2010). Ganges River Dolphin (Platanista gangetica) seeks help. Current Science 98(3): 287-288.

Bashir, T., A. Khan, J.A. Khan, P. Gautam \& S.K. Behera (2007). Aspects of ecology of Gangetic Dolphin (Platanista gangetica) in Western Uttar Pradesh, India. A survey report funded by WWF-India; Department of Wildlife Sciences, AMU, Aligarh, U.P, India, 68pp.

Bashir, T., A. Khan, P. Gautam \& S.K. Behera (2010). Abundance and prey availability assessment of Ganges River Dolphin (Platanista gangetica gangetica) in a stretch of upper Ganges River, India. Aquatic Mammals 36(1): 19-26.

Behera, S.K. (1995). Studies on Population Dynamics, Habitat Utilization and Conservation Aspects of for Gangetic Dolphin (Platanista gangetica) in a stretch of Ganga River from Rishekesh to Kanpur. PhD Thesis, School of Studies in Zoology, Jiwaji University Gawalior, 198pp.

Behera, S.K \& R.J. Rao (1995). Observation on the behaviour of Gangetic dolphins in the upper Ganga River. Journal of the Bombay Natural History Society 96: 43-47.

Behera, S.K. (2002). Status Report of Upper Ganga River (Bijnor to Narora), Ganges River Dolphin Conservation Project, World Wide Fund for Nature- India, 31pp.

Behera, S.K., V. Sagar \& A. Nawab (2008). Environmental flow requirements vis-à-vis habitat use pattern of freshwater dolphins. Proceedings of the 11th International River Symposium, Brisbane, Australia.

Choudhary, S.K., B.D. Smith, S. Dey \& S. Prakash (2006) Conservation and biomonitoring in the Vikramshila Gangetic dolphin Sanctuary, Bihar, India. Oryx 40(2): 189-197.

Gupta, D. (ed.) (1984). The Ganga Basin. Basin sub-Basin Inventory of Water Pollution. Part- II:ADSORBS/7/1982-83. Centre for Study of Man and Environment, Central Board for the Preservation and Control of Water Pollution, New Delhi, 204pp+7 annexes.

Hassan, S.S., R.K. Sinha, S.N. Ahsan \& N. Hassan (1998). Impact of fishing operation and hydrological factors on recent fish catch in Ganga near Patna, India. Journal of the Inland Fisheries Society of India 30(1): 1-12.

Jayaram, K.C. (1999). The Fresh Water Fishes of the Indian Region. Narendra Publishing House, 551pp.

Jones, S. (1982). The present status of the Gangetic susu, Platanista gangetica (Roxburgh), with comments on the Indus susu, $P$. minor (Owen) (Food and Agriculture Organization [FAO] Advisory Committee on Marine Resources Research, Working Party on Marine Mammals). FAO Fisheries Series 5: 97-115.

Lahvis, G.P., R.S. Wells, D.W. Kuehl, J.L. Stewart, H.L. Rhinehart \& C.S. Via (1995). Decreasing lymphocyte responses in free ranging Bottlenose Dolphins (Tursiops truncates) are associated with increased concentrations of PCBs and DDT in peripheral blood. Environmental Health Perspective 103(4): 67-72.

Mohan, R.S.L., S.C. Dey, S.P. Bairagi \& S. Roy (1997). On a survey of Ganges River Dolphins Platanista gangetica of Brahamputra River Assam. Journal of the Bombay Natural History Society 94: 483-495.

Nair, A.K. (2009). The status and distribution of major aquatic fauna in the National Chambal Gharial Sanctuary in Rajasthan with special reference to the Gangetic Dolphin Platanista gangetica gangetica (Cetartiodactyla: Platanistidae). Journal of Threatened Taxa 1(3): 141-146.

Newby, E. (1998). Slowly down the Ganges. Lonely Planet Publications, 23-25pp.

Nowak, R. (2003). Ganges and Indus Dolphins, or Susus, pp.128-130. In: Walker's Marine Mammals of the World, Vol. 2, $1^{\text {st }}$ Edition. The Johns Hopkins Univesity Press, Baltimore, MD.

Reeves, R.R. \& R.L. Brownell Jr. (1989). Susu Platanista gangetica (Roxburgh, 1801) and Platanista minor (Owen, 1853), pp.69-99. In: Hidgway, S.H. \& R. Harrison (eds.). Handbook of Marine Mammals, Vol. 4, Academic Press, London.

Reijinders, P.J.H. (1986). Reproductive failure of common seals feeding on fish from polluted waters. Nature 324: 456-57.

Sinha, R.K. (2000). Status of the Ganges river dolphins Platanista gangetica in the vicinity of Farakka Barrage India, pp.42-48. In: Biology and conservation of Freshwater Cetaceans in Asia. IUCN species survival commission occasional paper No.23 IUCN Gland, Switzerland.

Sinha, R.K. \& G. Sharma (2003). Current Status of the Ganges River Dolphin, in the river Kosi and Son, Bihar India. Journal of the Bombay Natural History Society 100(1): 27-37.

Smith, B.D. \& G.T. Braulik (2008). Platanista gangetica. In: IUCN 2010. IUCN Red List of Threatened Species. Version 2010.2. <www.iucnredlist.org>. Downloaded on 19 July 2010.

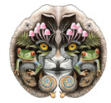

Author Details: TAWQIR BASHIR is a Senior Research Fellow at Wildlife Institute of India presently studying the ecology of high altitude carnivores in Eastern Himalaya for PhD programme. DR. AfIFULLAH KHAN is Chairman at the Department of Wildlife Science, Aligarh Muslim University, India. His research interests are to study the home range patterns, preypredator dynamics and landscape ecology using remote sensing and GIS. Dr. Sandeep Kumar Behera is a Senior Coordinator of the Ganges River Dolphin Programme at WWF-India and has been studying the ecology of Ganges River Dolphin in different tributaries of its distribution for the past two decades. DR. PARIKSHIT GAUTAM holds the chair of Director Freshwater and Wetland Division at WWF-India. His research interests mainly focus on the conservation of wetland biodiversity.

Author Contribution: Regarding both the study and the current paper, field data collection, data analysis and preparation of the manuscript/ paper was done by the first author. The remaining three authors were principal investigators and collaborators who contributed with their valuable suggestions and guided the first author all through the study. 